\title{
Financial Integration, Foreign Direct Investment and Growth: Panel Data Analysis for West African Economic Monetary Union countries (WAEMU)
}

\author{
Drama Bédi Guy Hervé ${ }^{1}$ \\ ${ }^{1}$ Département de Sciences Economiques et de Gestion Université Peleforo Gon, BP 1328 Korhogo-République de Côte \\ d'Ivoire. \\ Correspondence: Drama Bédi Guy Hervé, Département de Sciences Economiques et de Gestion Université Peleforo \\ Gon, BP 1328 Korhogo-République de Côte d'Ivoire.
}

Received: June 1, 2016

Accepted: June 14, 2016

Available online: June 23, 2016

doi:10.11114/aef.v3i4.1691

URL: http://dx.doi.org/10.11114/aef.v3i4.1691

\begin{abstract}
The main objective of this paper is to investigate the linkage between financial integration, foreign direct investment (FDI) and economic growth, of four West African countries namely Cote d'Ivoire, Benin, Senegal and Togo running the period of 1980 to 2014. To make the empirical investigation, I examine long-run equilibrium (cointegration) relationship among variables by using Pedroni $(1997 ; 1999 ; 2000)$ procedure. Then, I estimate a dynamic panel system GMM estimator proposed by Blundell and Bond (1998) with fixed effects approaches by utilizing Hausman test (1978). Finally, to verify the robustness of our estimators, I additionally perform panel Ordinary Least Squares method (OLS) and Two Stages Least Squares method (TSLS) Cumby et al. (1983). The overall results from the regression show that foreign direct investment (FDI) is not an important determinant of economic growth West Africa. However, its effect is relatively low and statistically insignificant at the conventional level. In addition, I found that financial integration variable impacts negatively growth in the four countries cited above, which signifies that financial integration policy doesn't allows financial system to be more efficient. Furthermore, the empirical results show that the effect of domestic own investment is globally positive and statistically significant for all countries when using panel least square framework. This stipulates that state own investment is determinant factors of economic growth in the region. The study finally suggests that structural strong macroeconomics reforms should be taken to strengthen policies through appropriate regulatory.
\end{abstract}

Keywords: Economic growth, financial integration, FDI, West African countries, Panel GMM.

\section{Introduction}

Developing countries, especially in Africa, recently considered the role of foreign direct investment (FDI) as essential to their development. FDI is an important engine because it provides the capital that these countries necessary need for investment and increases competition in host country industries while improving the productivity of local firms adopting more technologies effective or investing in human capital and or physical. Foreign direct investment contributes significantly to growth because it is more stable than other forms of capital flows. FDI yields more benefits than other types of financial flows because it comes with more direct control of management. For both developed and developing countries, there has been a substantial increase in the ratio of both gross external assets and liabilities to GDP, at the same time as an increased dispersion in absolute current account positions across countries Lane and Milesi-Ferretti (2006). Most low income economies such us West African countries adopted financial integration characterized by a decrease of cross-border financial transactions obstacles and accelerated foreign institutions in the local financial systems. The consequence of this major reform is to promote economic development through FDI. However the effects of these foreign investment on the concerning economies are subject of debate. Facing the exponential growth of foreign direct investment and the financial liberalization, several academicians have explored the link between foreign direct investment, financial integration and economic growth. See Levine and Zervos (1998); Bornschier and al (1978); Borensztein and al (1992); Tiwari and Mutascu (2010); Mensi and al. (2010) among other. The results are not clear because some authors like Bornschier and al (1978); Alfaro and al (2002) and Carkovic and Levine (2002) found no positive relationship between foreign direct investment and economic growth. In contrary, 
others theoretical and empirical studies have demonstrated positive, significant and long run effect on economic growth Türkcan and al (2008); Agrawal and Khan (2011); Adeniyi and al (2012).

With more than forty years reach literature to consider, the objective of this paper is investigate the effects of financial integration and foreign direct investment on the economic growth of four West African countries. In an others words, financial integration and foreign direct investment are really the main drivers of these economies? The rest of this article is organized as follow. The review of literature is depicted in section two. In section three, we deal with the model specification, the methodology utilized and the data sources. Then the empirical results and interpretation are highlighted in section four. Finally we conclude in the last section.

\section{Literature Review}

This section is divided in two subsections. First, the literature about the link between FDI and economic growth is addressed. This section provides the empirical evidence as well as its subsequent theoretical Explanations. Second section details the overview of the general relationship between financial development and economic growth. It then highlighted the debate on the role of financial development for the real economy.

\subsection{Foreign Direct Investment and the Real Economy growth: An Overview}

It is often claimed that FDI is an essential ingredient to economic growth solid and development, particularly because it's the main driver of the rapid and effective transfer and adoption of best practices from one country to another. Foreign direct investment is particularly adapted to the transfer and its transformation into global growth, specifically in making the most of human capital Klein, Aaron and Hadjimichael (2001). We know now that FDI lead to the reduction of poverty, it's also factor of growth.The literature on the FDI-growth relationship is reach for both developed and developing countries and explores various aspects of FDI effects on real economy.

The theory provides conflicting predictions about the effects of FDI on growth. Indeed, FDI can play in different ways on the overall process of development see Addison and Mavrotas, (2004). First, it is a source accumulation of capital, both physical and human. Since the FDI projects are carefully designed, they cause growth and contribute to creating jobs and stimulating employment. This effect on employment means that FDI can contribute to reducing income poverty. Then those incomes that State needs may be used to finance infrastructure and services related to the development. Thus, the benefits of such income are direct and indirect. Direct aspects concern the corporate income tax paid to the State by the companies themselves and the revenues from FDI in the natural resource sector. Indirect aspect is related to increasing economic growth when it results in improved the overall tax base. Furthermore, studies across countries and industries have shown the positive impact of FDI on economic growth. The research performed by Obwona (1999) on Uganda identified positive link between FDI and growth, as in the paper prepared by Chen et al (1995) found the same phenomenon in China. Similarly, Bielschowsky (1994) and Kokko et al (1996) found a positive impact of FDI on productivity of labor and growth in the manufacturing industry Brazil and Uruguay respectively.

However, Macroeconomic empirical literature does not really confirms exogenous positive effect of FDI on economic growth. The interaction between FDI and economic growth does not happen automatically. The previous empirical work on this topic display contradictory results: on 72 developing countries between 1960 and 1978, Jackman (1982) showed that FDI has no effect on growth once the size of the countries is considered. In another study, Rothgeb (1984) observed that FDI was negatively related to growth for all 18 African countries as well, while for all Latin America countries, its impact on growth was positive. From the literature, it is clear that the ability of a country to benefit from the positive effects of FDI may be limited by local conditions such as the development of local financial markets or the level of education in the host country; this phenomenon is called the absorption capacity. Borensztein et al (1998) and Xu (2000) show that FDI brings technology, resulting in increased growth, but only to the extent that the host country has a minimum threshold of human capital. Alfaro et al (2004), Durham (2004) and Hermes and Lensink (2003) provide evidence that only countries with well developed financial markets benefit significantly from FDI in terms of growth rates. The paper performed by Ikiara (2003) attempted to assess Africa's performance against FDI, including the extent to which FDI contributes to growth and poverty reduction. The results relating to FDI and technology transfer are mainly from African manufacturing firms. The number of studies on the link between FDI and technology transfer in Africa is limited. Some indicative results come from Wangwe (1995) and relate to six African countries: Cote d'Ivoire, Kenya, Mauritius, Nigeria, Tanzania and Zimbabwe. The study of Biggs and Srivasta (1996) focuses on Ghana, Zimbabwe and Kenya. Among other documents are: Hadda and Harrison (1993) on Morocco; Gershenberg (1997) on Kenya; Phillips et al (2000) on Mauritius, Uganda and Kenya.

\subsection{Financial Development and Economic Growth.}

For more than a century, economists have been debating the important relationship between finance and growth. The key issue centers on whether and how a well-functioning financial system could promote long-run economic growth. More recently, Gelb (1999), Ghani (1992), and a series of papers by King and Levine (1993a, 1993b, and 1993c) 
present empirical evidence linking economic growth to financial depth (as measured by banking development) in broad cross-economy setting. More specifically, King and Levine construct four indicators of financial development and three growth measures for simple of eighty countries over the period of 1960 to 1989. Using the cross-countries regression methodology, they study the overall impact of financial development on growth and specific channels through which financial development might influence growth, capital accumulation and technological innovation. They find that even after taking into account the initial level of growth as well as controlling for other determinants of growth, the initial level of financial development is strongly associated with subsequent long-run growth rates, capital accumulation, and productivity enhancement. Similar studies have confirmed the same results see Rajan and Zingales, (1998); Demirgucs-Kunt and Maksmovic (1996a, 1996b); Cameroun et al. (1967); Habeer, (1991); McKinnon, (1973). However, these results based on a broad cross section of countries do not completely settle the issue of causality. A number of studies have questioned the robustness as well as the economic implications of the cross-country regression methodology Evans, (1995); Lee, Pesaran, and Smith, (1996); Arestis and Demetriades (1996); King and Levine (1996b).

Moreover, during particular time periods in history, financial systems had contributed significantly to economic growth in some countries. Unfortunately, since these countries studies rely more on descriptive than formal statistical analysis, their findings are often considered less systematic and subject to much debate. This, however, leads to related important question: which forms of financial development are more conducive to long-run economic growth? In other words are there particular financial structures and particular patterns of financing more favorable to growth? Understanding this issue could have profound policy implications as to what specific public policies should be implemented, in order to achieve an optimal financial system. Clearly, this issue is especially relevant to developing countries and transitional economies such as WAEMU where the financial system is currently undergoing major transformations.

\section{Regression specification, Methodology applied and Data sources.}

\subsection{Regression Specification}

To explore long-run relationship between FDI, financial integration and economic growth we base our analysis on the model employed by Alfaro (2003), Brezigar-Masten and al (2008), Anwar and Nguyen (2010). Therefore, the following econometric model is specified as follow:

$$
G D P_{i t}=\alpha_{0}+\alpha_{1} F D I_{i t}+\alpha_{2} D F I_{i t}+\alpha_{3} D I N V_{i t}+\alpha_{4} E X R_{i t}+\alpha_{5} I N F_{i t}+\alpha_{6} F D_{i t}+\alpha_{7} T O P_{i t}+\mu_{i t}
$$

Where:

$G D P_{i t}=$ Logarithmic of growth in real GDP per capita for each country selected.

$F D I_{i t}=$ Foreign direct investment that is measured by the inflows of capital accruing to country $i$ in year $t$.

$F I_{i t}=$ Financial integration proxy of domestic credit to private sector as a percentage of GDP.

$I N V_{i t}=$ The nationally owned investments defined as gross fixed domestic investment.

$T O P_{i t}=$ The Trade Openness measured by the sum of imports and exports in percentage of GDP.

$E X R_{i t}=$ The real exchange rate variable calculated from nominal exchange rates and consumer price index.

$F D_{i t}=$ The development of domestic financial systems proxy to the money supply as a share of per capita $G D P$.

$I N F_{i t}=$ The inflation rate which represents the Consumer Price Index.

$\mu_{i t}=$ the error term to country $i$ in year $t$.

\subsection{Methodology applied for empirical investigation.}

To analyze the relationships between FDI, financial integration and economic growth in four West African countries running the period of 1980 to 2014, the panel unit roots namely (LLC) Levin Lin and Chu (2002), Im, Pesaran and Shin (2003) (IPS) and Hadri (2000) is performed to verify the stationarity of the data base. As the involvement of macroeconomic applications in the panel data analyses has been growing recently, the Dickey-Fuller and Augmented Dickey-Fuller tests are required to be extended for testing stationarity in panel data analysis. When dealing with panel data, because the procedure is more complex, the ADF and DF tests can result in inconsistent estimators. Thus, the stationarity of the series should be tested by using three different types of tests, namely ( $L L C)$ (Levin, Lin and Chu 
(2002); (IPS) Im, Pesaran and Shin (2003) and Hadri, (2000) to verify the stationarity. In the analysis, firstly the (LLC) test is employed to verify the stationarity. Levin, Lin and Chu (2002) model allows heterogeneity of individual deterministic effects and heterogeneous serial correlation structure of the error terms assuming homogeneous first order autoregressive parameters. In addition the model provides two-way fixed effects, one of which comes from the term $\alpha_{i}$ and the other one emanates from $\delta_{t}$ Barbieri (2005). Moreover, these two parameters allow for heterogeneity, as the coefficient of lagged $Y_{t}$ is limited to be homogenous through all individual units of the panel. Therefore the operator equation is depicted as follow:

$$
\Delta Y_{i, t}=\alpha_{i}+\ell_{i} Y_{i, t-1}+\sum_{k=1}^{n} \varphi_{k=1} \Delta Y_{i, t-k}+\lambda_{i t}+\delta_{t}+\varepsilon_{i t} \quad \text { with } \mathrm{i}=1 \ldots \mathrm{N} ; \mathrm{T}=1 \ldots \mathrm{T}
$$

We second examine long-run equilibrium (cointegration) relationship among variables by using Pedroni (1997; 1999; 2000) procedure. Then, we estimate a dynamic panel system GMM estimator proposed by Blundell and Bond (1998) with fixed effects approaches by utilizing Hausman test (1978). Finally, to verify the robustness of our estimators, we additionally perform panel Ordinary Least Squares method (OLS) and Two Stages Least Squares method (TSLS) Cumby et al. (1983).

\subsection{Data sources}

To examine the effects of foreign direct investment, financial integration and economic growth in the four West African countries (Cote d'Ivoire, Ghana, Nigeria and Senegal), we use data from 1980 to 2014. The data utilized for the analysis have been collected from a various international databases such as the World Development Indicators (WDI) and the World Economic Outlook Database (IMF).

\section{Empirical results and Interpretation.}

\subsection{Empirical Results}

In this subsection, we first start by viewing the summary of descriptive statistics of our variables depicted in table 1 bellow. All variables exhibit a positive mean return. Also the sum squared deviation row represents the net change over the sample period. In terms of skewness, all variables are positively skewed excepted real growth per capita and national owned investment which displays negative sign. This result implies that real growth and investment have a long left tail. All variables are relatively normally distributed as indicated by the $\mathrm{p}$ values of Jarque Bera statistic.

Table 1. Summary of descriptive statistics

\begin{tabular}{lcccccccc}
\hline & LnGDP & FDI & FI & INV & EXR & INF & FD & TOP \\
\hline Mean & 0.012 & 1.576 & 22.533 & 13.490 & 357.17 & 4.448257 & 29.66767 & 71.09713 \\
Median & 0.372 & 1.224 & 22.520 & 14.129 & 321.90 & 2.474268 & 27.63104 & 68.45874 \\
Maximum & 12.25849 & 19.37574 & 42.26380 & 36.42837 & 754.91 & 39.16277 & 48.97571 & 151.1841 \\
Minimum & -17.11439 & -2.069713 & 5.415283 & -22.80522 & 77.245 & -4.876982 & 19.50703 & 38.23769 \\
Std. Dev. & 4.153455 & 2.042649 & 8.174029 & 7.793278 & 257.7422 & 6.674783 & 7.502769 & 18.66935 \\
Skewness & -0.514439 & 4.851495 & 0.352909 & -0.738638 & 0.168486 & 2.689302 & 0.753371 & 0.739030 \\
Kurtosis & 5.831426 & 42.43305 & 2.488813 & 5.863334 & 1.262814 & 12.28249 & 2.474765 & 4.152330 \\
Jarque-Bera & 52.94076 & 9619.829 & 4.430374 & 60.55600 & 18.26629 & 671.3811 & 14.85248 & 20.48973 \\
Probability & 0.000000 & 0.000000 & 0.109133 & 0.000000 & 0.000108 & 0.000000 & 0.000595 & 0.000036 \\
Sum & -1.753590 & 220.7384 & 3154.673 & 1888.615 & 50004.06 & 622.7560 & 4153.473 & 9953.599 \\
Sum Sq. Dev. & 2397.915 & 579.9657 & 9287.250 & 8442.190 & 9233917. & 6192.829 & 7824.524 & 48447.69 \\
Observations & 140 & 140 & 140 & 140 & 140 & 140 & 140 & 140 \\
\hline
\end{tabular}

Source: Own computation of the data use in the regression.

Second, the Dickey-Fuller and Augmented Dickey-Fuller tests are required to verify the presence of unit root but the procedure need to be extended for testing stationarity in panel data analysis. When dealing with panel data, because the procedure is more complex, the ADF and DF tests can result in inconsistent estimators. Thus, the stationarity of the series should be tested by using three different types of tests, namely (LLC) Levin, Lin and Chu (2002); (IPS) Im, Pesaran and Shin (2003) and Hadri (2000). The results are provided by table (2a; 2b). Table 2a shows that the presence of unit roots could not be rejected at level. Nevertheless, when one takes the first difference of the variables, it can be 
noted that all of the variables have unit root in not only individual intercept case, but intercept and trend situations, as well. IPS test has the same null hypothesis of having unit roots as $L L C$ test. However, it assumes individual unit root process as stated above. This test also indicated a positive result in testing the presence of unit roots of series just like the $L L C$ test results. In addition to the previous tests, Hadri test is also implemented highlight positive result as table $2 \mathrm{~b}$ points out. As a result, these outcomes obtained from panel unit root tests allowed us to go on to cointegration tests. In another words, all tests mentioned above indicate that all variables are non-stationary at level while they are all stationary at first difference. Thus, according the empirical foundation; we found that all variables follow the process.

Table (2a; 2b). Panel Unit Roots

Table 2a: Panel Unit Roots at Level

\begin{tabular}{cllll} 
Variables & & \multicolumn{2}{c}{ Commun unit roots } & HADR \\
Individual \\
IPS
\end{tabular}

Table 2a: Panel Unit Root Test at First Difference

\begin{tabular}{ccccc} 
Variables & & \multicolumn{2}{c}{ Commun unit roots } & Individual \\
& situations & LLC & HADRI & IPS \\
\hline GDP & Individual & $-8,34(0,000)$ & $0,425(0,005)$ & $-7,950(0,0000)$ \\
& Intercept \& trend & $-8,117(0,000)$ & $2,847(0,0022)$ & $-7,560(0,000)$ \\
FDI & Individual & $-7,242(0,000)$ & $-0,614(0,7302)$ & $-6,507(0,000)$ \\
& Intercept \& trend & $-6,692(0,000)$ & $-0,613(0,730)$ & $-6,097(0,000)$ \\
DFI & Individual & $-3,905(0,000)$ & $1,080(0,0009)$ & $-3,349(0,0004)$ \\
& Intercept \& trend & $-4,231(0,000)$ & $0,979(0,007)$ & $-3,253(0,0006)$ \\
INV & Individual & $-0,860(0,000)$ & $1,535(0,0062)$ & $-2,665(0,0003)$ \\
& Intercept \& trend & $-1,834(0,000)$ & $0,5948(0,002)$ & $-2,910(0,910)$ \\
EXR & Individual & $-4,024(0,0000)$ & $-4,436(0,668)$ & $-4,828(0,0000)$ \\
\multirow{2}{*}{ INF } & Intercept \& trend & $-3,238(0,0006)$ & $-0,362(0,641)$ & $-4,282(0,000)$ \\
& Individual & $-6,139(0,000)$ & $-0,1300(0,551)$ & $-6,587(0,000)$ \\
\multirow{2}{*}{ FD } & Intercept \& trend & $-5,311(0,000)$ & $1,363(0,086)$ & $-6,1338(0,000)$ \\
& Individual & $-7,347(0,000)$ & $0,3154(0,371)$ & $-6,247(0,000)$ \\
TOP & Intercept \& trend & $-7,347(0,000)$ & $1,425(0,077)$ & $-6,268(0,0000)$ \\
& Individual & $-4,779(0,000)$ & $-0,323(0,626)$ & $-4,258(0,000)$ \\
& Intercept \& trend & $-4,289(0,000)$ & $0,794(0,214)$ & $-3,714(0,0001)$ \\
\hline
\end{tabular}

Source: Own computation from the data use for regression

Note: All tests use Schwarz Information Criteria (SIC) for lag selection. In the first generation tests, the values in brackets are the P-values. For the case with constant, critical values for Pesaran CIPS test are: $-2.53,-2.32 ;-2.21$ for $1 \%$, 5\% and $10 \%$ significance levels, respectively. For the case with drift and trend, critical values are $-3.03,-2.83$ and -2.72 for $1 \%, 5 \%$ and $10 \%$ significance levels, respectively.

Third, as our variables follow the $I$ (1) process the important step of our analysis is to run the cointegration test. The 
concept of cointegration implies that there is a short-run and long run relationship between economic variables in other words, the independent and dependent variables are stable during the study period. In so doing, we performed simultaneously both Johansen cointegration and panel cointegration test utilizing the methodology developed by Pedroni (1997, 1999 and 2000). The results are outlined by table 3. Moreover, the stationarity and the cointegration test results will allow us to better specify the dynamic panel GMM and TSLS estimator.

Table 3. Panel Cointegration (Pedroni procedure)

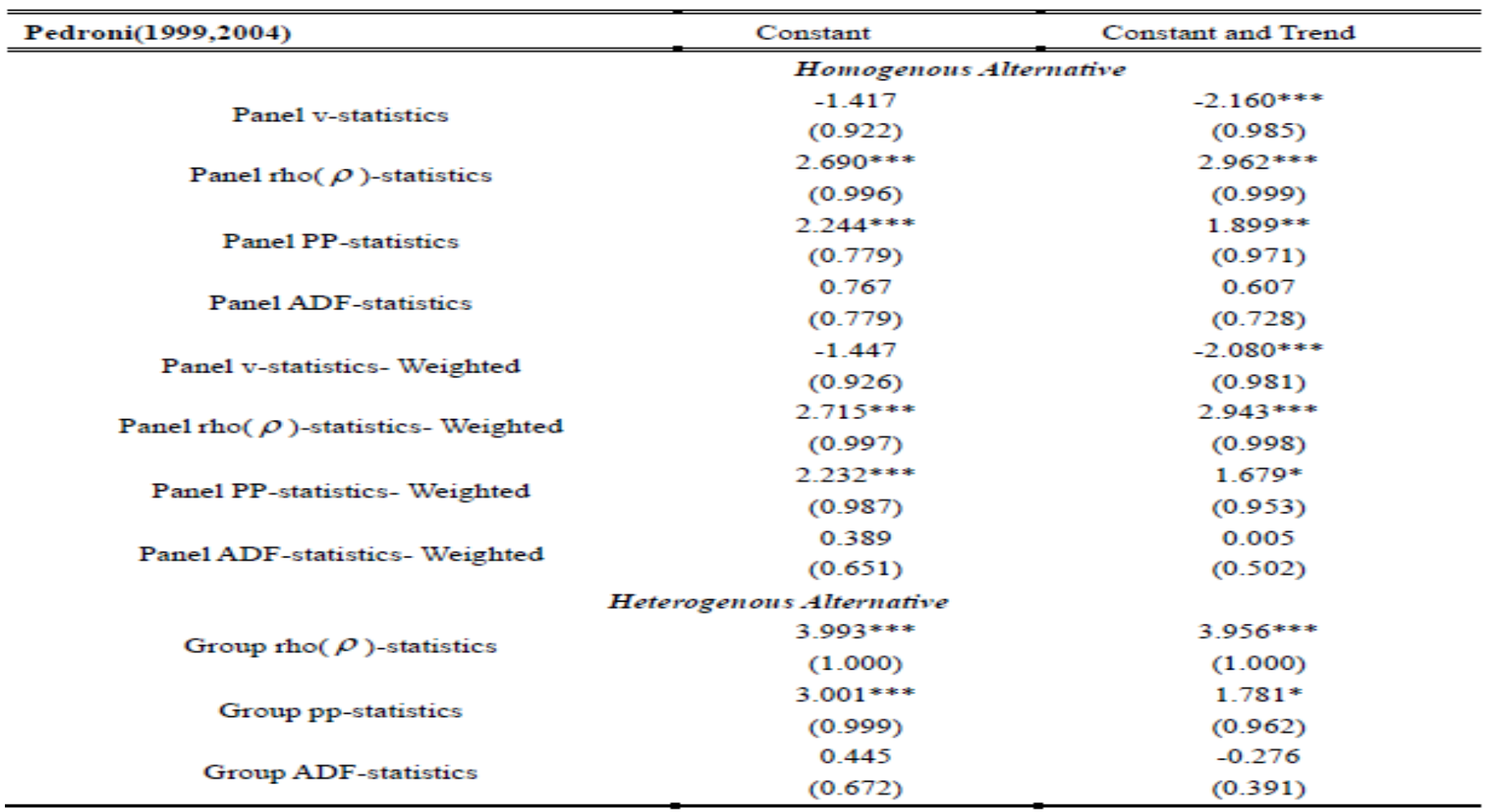

Source: Own computation.

Note: F-test result indicates the overall significance of the model. The asterisks ***,** and * implies statistically significant at $1 \%, 5 \%$ and at $10 \%$ level respectively.

Finally, in order to ascertain the relationship that exists between our variables, we perform panel ordinary least square estimate (OLS) of linear regression to provide value for the coefficient of the models. Similarly, dynamic panel GMM and TSLS econometric estimation are also adopted. The results reported in Tables 4 and 5.

Table 4. Ordinary Least Square and Panel Least Square.

\begin{tabular}{|c|c|c|c|c|c|}
\hline & Ordinary & Least Square & Individual & by Country & $\begin{array}{l}\text { Commum Panel Least } \\
\text { Square fixed effects }\end{array}$ \\
\hline Variables & CIV & BENIN & SENEGAL & TOGO & \\
\hline \multirow[t]{2}{*}{ FDI } & -0.175 & -0.041 & 0.079 & 0,20 & 0.194 \\
\hline & $(1.027)$ & $(0.338)$ & $(0.469)$ & $(0.289)$ & $(0.174)$ \\
\hline \multirow[t]{2}{*}{ DFI } & -0.298 & 0.003 & $-0.139^{*}$ & -0.034 & $-0.134^{* x}$ \\
\hline & $(1.136)$ & $(0.079)$ & (0.083) & $(0.0258)$ & $(0.043)$ \\
\hline \multirow[t]{2}{*}{ INV } & 0.3 & 0.126 & $0.147 \times x$ & 0.416 & $0.099^{x-x}$ \\
\hline & $(0.232)$ & $(0.178)$ & $(0.045)$ & $(0.301)$ & $(0.046)$ \\
\hline \multirow{3}{*}{$\begin{array}{l}\text { CONTROL } \\
\text { VARIABLES }\end{array}$} & -0.141 & 0.222 & 0.005 & 0.109 & 0.039 \\
\hline & $(0.092)$ & (0.084) & $(0.074)$ & $(0.071)$ & $(0.025)$ \\
\hline & $R^{2}=0.46$ & $\mathbf{R}^{2}=0.31$ & $\mathbf{R}^{2}=0.44$ & $\mathbf{R}^{2}=0.37$ & $R^{2}=0.16$ \\
\hline
\end{tabular}

Source: Own computation.

Note: Dependant variable: growth rate of real per capita GDP. $(* * *),(* *)$ and $(*)$ indicate statistical significance at the $1 \%, 5 \%$ and $10 \%$ level, respectively. Values between brackets are Standard Error. 
Table 5. Panel Generalized Method of Moment (GMM) and Panel Two Stage Least Square TSLS.

\begin{tabular}{|ccccc|}
\hline $\begin{array}{l}\text { Dependant variable GDP } \\
\text { Panel GMM } \\
\text { N=140 observations }\end{array}$ & & & & \\
\hline \multicolumn{1}{|l}{ Variables } & coefficients & std Error & T-stat & prob \\
\hline FDI & 4,125 & 11,755 & 0,351 & 0,946 \\
\hline $\boldsymbol{I N V}$ & 4,526 & 6,377 & 0,709 & 0,483 \\
\hline $\boldsymbol{F I}$ & 0,295 & 1,94 & 0,247 & 0,806 \\
\hline $\boldsymbol{C}$ & 1,44 & 21,247 & 0,0675 & 0,946 \\
\hline $\begin{array}{l}\text { Control } \\
\text { Variables }\end{array}$ & $-0,371$ & 0,373 & $-3,473$ & 1,714 \\
\hline
\end{tabular}

Dependant variable GDP

Panel TSLS

$N=140$ observations

\begin{tabular}{|ccccc|}
\hline Variables & coefficients & std Error & T-stat & prob \\
\hline FDI & 4,125 & 11,755 & 0,351 & 0,946 \\
\hline $\boldsymbol{I N V}$ & 4,526 & 6,377 & 0,709 & 0,483 \\
\hline $\boldsymbol{F I}$ & 0,295 & 1,94 & 0,247 & 0,806 \\
\hline $\boldsymbol{C}$ & 1,44 & 21,247 & 0,0675 & 0,946 \\
\hline $\begin{array}{l}\text { Control } \\
\text { Variables }\end{array}$ & $-0,371$ & 0,373 & $-3,473$ & 1,714 \\
\hline
\end{tabular}

Source: Own computation from data use in the regression.

Note: Dependant variable: growth rate of real per capita GDP. $(* * *),(* *)$ and $(*)$ indicate statistical significance at the $1 \%, 5 \%$ and $10 \%$ level, respectively. Values between brackets are Standard Error.

\subsection{Interpretation of the results.}

Having confirmed that all variables included in the causality test are integrated of order one, the next step is to test for the existence of a cointegration relationship among the variable series using the Pedroni's approach methodology. As we know, Pedroni computed seven statistics to test the null of no cointegration among series. For these series, the critical value is -1.64 except which v-statistics has 1.64 . That's to say, when the test statistic is lower than -1.64 , (greater than 1.64 for $v$-statistics), then the null hypothesis is rejected. Table 3 reports these seven statistics for real growth per capita and it determinants. As it can easily be understood from table 3 above, there is a strong cointegration between six (7) variables in both individual and individual intercept and trend situations. On the other hand, the results point out a remarkable cointegration between all variables. The Pedroni's panel cointegration test for both cases unweighted and weighted confirm also the cointegrating relationship between all variables.

The overall results from the regression show that foreign direct investment (FDI) is not an important determinant of economic growth West Africa. However, its effect is relatively low and statistically insignificant at the conventional level $1 \% ; 5 \%$ and $10 \%$. This means that there are many obstacles in attracting foreign investment in domestic economy (poor macroeconomic environment, corruption, lake of adequate infrastructure, political stability, insecurity etc...). In addition, the study demonstrate that financial integration variable impacts negatively growth in the selected countries cited above, which signifies that financial integration policy is not efficient. Beyond what we mentioned above, our empirical results show that the effect of domestic own investment is globally positive and statistically significant for all countries when using panel least square framework. This stipulates that state own investment is the main determinant of economic growth rate in the zone. Furthermore, the control variables (trade openness, financial development, exchange rate etc.) have a negative effect on selected countries economic growth which means that the reforms impact are insignificant; this situation is due to the poor macroeconomic environment, political instability in recent years. From these results, the research confirms that financial integration policy doesn't allow these countries to reinforce their economies through the creation of common currency area.

\section{Conclusion}

The main objective of this paper was to examine the relationship between financial integration, foreign direct investments and economics growth in four West African countries namely, Benin, Cote d'Ivoire, Togo and Senegal. To solve our problem, the panel OLS, the dynamic panel system GMM estimator proposed by Blundell and Bond (1998) and TSLS running the period of 1980 to 2014 is used. The outcome of our empirical investigation demonstrates that FDI contribution to these economies cited above are quite insignificant at the conventional level during the study period. In other words, FDI plays a negative role in boosting the economic growth of West African countries. Results show that the implementations of regional integration last pass decades such as monetary integration, financial union, adoption of common currency, and free trade area has been inefficient at all for these economies. In fact, FDI couldn't stimulate positively growth in the region; perhaps because lake of research and development level, inadequate human capital development and low level of international trade. We can conclude that, despite, the recent spectacular economy growth, west African countries have achieved significant steps of economic and financial development; our observation is that the contribution of financial integration remains very low and insignificant. This situation is due to poor level of 
infrastructure, low productivity and corruption among other. Considering that these countries are low income countries, we suggest that structural strong macroeconomics reforms should be taken to strengthen policies such as economic, commercial, banking, climate and harmonization of business environment. Beside what we mentioned above, some obstacles such as investment environment, free capital movement, free trade area and common currency policy should be reinforce in order to facilitate financial integration. This can improve growth in each country.

\section{References}

Acemoglu, D., Aghion P., \& Zilibotti, F. (2003). Vertical Integration and Distance to Frontier, Journal of European Economic Association, 630-638.

Acemoglu, D., Aghion, P., \& Zilibotti, F. (2006a). Distance to Frontier, Selection, and Economic Growth, Journal of the European Economic Association, March 2006, 4(1), 37-74.

Aghion, P., Howitt, P., \& Mayer-Foulkes, D. (2005). The E_ect of Financial Development on Convergence : Theory and Evidence _, Quarterly Journal of Economics 120 (Fevrier 2005), 173-222.

Agrawal, G., \& Khan, M. A. (2011), "Impact of FDI on GDP Growth: A Panel Data Study", European Journal of Scientific Research, 57(2), 257-264.

Alfaro, L., Chanda, A., Kalemli-Ozcan, S., \& Sayek, S. (2006), "How Does Foreign Direct Investment Promote Economic Growth? Exploring the Effects of Financial Markets on Linkages", NBER Working Paper, No. 12522, September.

Alfaro, L., Chanda, A., Kalemli-Ozcan, S., \& Sayek, S. (2006). How Does Foreign Direct Investment Promote Economic Growth? Exploring the Effects of Financial Markets on Linkages, Harvard Business School, and Working Paper.

Arestis, P., \& Demetriades, P. (1996). Finance and Growth: Institutional Considerations and Causality _, Working Paper 9605, University of East London, Department of economics.

Arestis, P., \& Demetriades, P. (1998), Finance and Growth: Is Schumpeter Right? Analyze Economica, 16(30), 5-21.

Arrow, K. J. (1979), Pareto Effciency with Costly Transfers_, Economic Forum, 10, 1-13. Beck, T.,

Aviral Tiwari and Mihai Mutascu (2010). Economic growth and and FDI in ASIA: A panel data approach. MPRA Paper No. 28172 posted 18. UTC

Beck, T., \& Levine, R. (2002),Industry Growth and Capital Allocation: Does Having a Market- or Bank-Based System Matter? , Journal of Financial Economics, 64 ,147-180,

Beck, T., \& Levine, R. (2004), Stock Markets, Banks and Growth: Panel Evidence _, Journal of Banking and Finance, 423-442.

Bencivenga, V. R., \& Smith, B. D. (1991), Financial Intermediation and Endogenous Growth, Review of Economics Studies, 58, 195-209.

Borensztein. (1992). How does foreign direct investment affect economic growth? Journal of International Economics 45 (1998) $115-1$

Bornschier, V., Cao, B., \& Thanh, H. (1978). Multinational Corporations in the World Economy and National Development: An Empirical Study of Income per Capita Growth, 1960-1975. Zürich, Switzerland: University of Switzerland, Sociological Institute.

Demirguc-Kunt, \& Levine, R. (2001), The Financial Structure Database,In : Financial Structure and Economic Growth : A Cross-Country Comparison of Banks, Markets, and Development_,Eds : A. Cambridge, MA : MIT Press, 17-80.

Fuller, W. (1979). Dickey, D.A. and W.A. Fuller (1979), "Distribution of the Estimators for Autoregressive Time Series with a Unit Root,. Journal of the American Statistical Association, 74, p. 427-431

Hadri, K. (2000). "Testing for Stationarity in Heterogeneous Panel Data”. Econometrics Journal 3, 148-161.

Leipzig, D., \& Humblot. (1912). Translated by Redvers Opie, Cambridge, MA : Harvard University Press, 1934.

Levine, \& Zervos (1998). Stock Markets, Banks, and Economic Growth. The American Economic Review, 88(3).

Levine, R. (1997). Financial Development and economic Growth: Views and Agenda _, Journal of Economic Litterature, 688-729.

Levine, R. (2001). "International Financial Liberalization and Economic Growth", Review of International Economics, 9(4), 688-702. 
Levine, R. (2002). Bank-Based or Market-Based Financial Systems: Which Is Better? , Journal of Financial Intermediation, 11, 398-428.

Levine, R. (2005). Finance and growth: theory and evidence, in P. Aghion and S. Durlauf (eds.), Handbook of Economic Growth, Amsterdam : North-Holland, 866-934.

Levine, R., \& Zervos, S. (1998a). Stock Markets, Banks, and Economic Growth _, American Economic Review, 88, 537-558.

Lucas, R. E. (1988). on the Mechanics of Economic Development_, Journal of Monetary Economics, 22 , 3-42.

Maria Carkovic and Ross Levine (2002): Does Foreign Direct Investment Accelerate Economic Growth? Finance Department, Carlson School of Management, University of Minnesota, 19 Avenues South, Minneapolis, MN 55455

Merton, R. C. (1995). A Functional Perspective of Financial Intermediation_Financial Management, 24, 23-41.

North, D. C. (1981). Structure and Change in Economic History _, New York: Norton.

Pedroni, P. (1997,1999 \& 2000). "Critical Values for Cointegration Tests in Heterogeneous Panel with Mutiple Regressor". Oxford Bulletin of Economics and Statitics Special Issue 0305-9049.

Pesaran, H., Shin, Y., \& Smith, R. (2001). Bounds Testing Approaches to the Analysis of Level Relationship. Journal of Applied Econometric 16, 289-326.

Phillips, P. (1988). Testing for a Unit Root in Time Series Regression". Biometrika, 75, 335-346.

Rajan, R., \& Zingales, L. (1998). Financial Dependence and Growth _, American Economic Review, 88, $559-586$.

Saint-Paul, G. (1992). Technological Choice, Financial Markets and Economic Development, European Economic Review, 36, 763-781.

Schumpeter, J. (1912). Theorie der Wirtschaftlichen Entwicklung [The Theory of Economic Development]

Smith, Adam (1776). an Inquiry into the Nature and Causes of the Wealth of Nations, London: W. Stahan \& T. Cadell, 1776.

Stiglitz, J., \& Weiss, A. (1981). Credit Rationing in Markets with Imperfect Information, Amecican Economic Review, June 1981, 71(3), 393-410.

Stiglitz, J., \& Weiss, A. (1983). Incentive Effects of Terminations: Applications to Credit and Labor Markets _, Amecican Economic Review, 73(5), 912-927.

Stulz, R. M. (2001). Does Financial Structure Matter for Economic Growth? A Corporate Finance Perspective _, In : Financial Structure and Economic Growth : A Cross-Country Comparison of Banks, Markets, and Development, Eds : A. Demirguc-Kunt and R. Levine. Cambridge, MA: MIT Press, 143-188

\section{(cc) $\mathrm{Br}$}

This work is licensed under a Creative Commons Attribution 3.0 License. 